\title{
Síntese da gramática tensiva
}

Claude Zilberberg

Séminaire Intersémiotique de Paris 


\section{Resumo}

Este trabalho apresenta três características que podem parecer um pouco desconcertantes. Em primeiro lugar, ele não se contenta em convidar a afetividade para tomar parte na produção do sentido; ele lhe confia a direção desse processo, em nome do princípio de imanência (Hjelmslev). Em segundo lugar, nosso estudo propõe que sobre a semiótica das oposições - a qual continua em vigência no estruturalismo - prevaleça uma semiótica dos intervalos, reconhecendo a primazia da afetividade, uma vez que nossas vivências são antes de mais nada (e talvez nada mais que) medidas. Enfim, ambos os pontos mencionados pressupõem a centralidade do acontecimento, a fascinação do discurso pela dimensão concessiva do acontecimento. Se admitirmos tais preliminares, tenderemos a desvincular a semiótica da narratividade e a aproximá-la da retórica tropológica.

\section{Palavras-chave}

acontecimento, afetividade, estrutura, sentido, semiótica, tensividade

\section{Abstract}

We present in this work three main theses that could sound a little bit unsettling. First, not only do we invite affectivity to play some role in meaning production, but moreover, in the name of Hjelmslev's principle of immanence, we assume it to direct the production of meaning. Second, we suggest topping off structuralist semiotics of oppositions with a semiotics of intervals in which primacy is given to affectivity, inasmuch as our experiences are, above all, measures, if not measures only. Finally, we try to show that both points mentioned presuppose the central role of the event, as well as the fascination of discourse for the concessive dimension of the event. Once admitted, these preliminaries tend to help detaching semiotics from the narrative, bringing it closer to tropological rhetoric instead.

\section{Keywords}

event, affectivity, structure, meaning, semiotics, tensivity 
O sujeito perceptual deixa de ser um sujeito pensante " acósmico »; a

ação, o sentimento e a vontade permanecem por explorar como maneiras originais de apresentar um objeto, dado que « um objeto mostra-se atraente ou repulsivo, antes de mostrar-se negro ou azul, circular ou quadrado ».

Merleau-Ponty, citando Koffka

\section{Declaração dos postulados}

$\prod$

endo perdido sua inocência e seu poder oracular, o discurso teórico tem a obrigação de apresentar a lista dos ingredientes que compõem o valor a que ele aspira.'

O primeiro postulado que mencionaremos é o apego à estrutura, mais que ao estruturalismo, pois, considerando-se o que ocorreu durante

1. A maior ou menor dimensão de um discurso teórico depende de muitas variáveis, suscitando a necessidade de introduzir grandezas metalingüisticas que explicitem o conteúdo e a extensão dos termos utilizados; essa passagem da denominação à definição leva em conta o conteúdo dos termos e a suposta competência dos destinatários. No que tange ao conteúdo, a novidade, isto é, o legivel hoje em dia, exige, do ponto de vista fiduciário, uma discussão argumentativa, bem como a refutação antecipada das objeções previsiveis; as ilustrações de praxe alongam ainda mais o texto. A cada instante, o discurso está atrelado ao dilema: estender ou reduzir? Todo discurso está como que perseguido por sua própria negatividade, como que minado pela atualização daquilo que se poderia ou deveria ter acrescentado, ou pela virtualização do que poderia ou deveria ter sido retirado. Desse modo, a elasticidade do discurso, no plano da expressão, e a arbitrariedade no plano do conteúdo são sintomas de que a realização está longe de anular o realizável. Em muitos casos, o alcance desses dados internos fica neutralizado pelas convenções e circunstâncias: o destinador-solicitante define uma extensão desejável, "se possível, sem ultrapassá-la". Fomos, assim, convidados por Louis Hébert a expor os conceitos mestres da semiótica tensiva - convidados, em suma, a fazer um balanço. 
as últimas décadas, o termo impõe-se no plural: os estruturalismos. A definição de estrutura dada por Hjelmslev em 1948 permanece, a nosso ver, intacta: "entidade autônoma de dependências internas". De tal definição, que se ajusta à definição da "definição" proposta nos Prolegômenos, frisaremos o fato de ela combinar uma singularidade ("entidade autônoma") e uma pluralidade ("dependências internas"). Em primeiro lugar, esse ajuste remete, no plano do conteúdo, a uma complementaridade proveitosa: (i) se a singularidade não estivesse acompanhada por uma pluralidade, ela permaneceria impensável, pois que não analisável; (ii) se a pluralidade não pudesse ser condensada e resumida em e por uma singularidade nomeável, ela permaneceria no umbral do discurso, a exemplo da interjeição. Em segundo lugar, essa definição vai além do adágio segundo o qual, para o estruturalismo, a relação prevalece sobre os termos; a economia do sentido apreende unicamente relações entre relações, uma vez que "os 'objetos' do realismo ingênuo reduzem-se, então, a pontos de interseção desses feixes de relacionamentos" (Hjelmslev, 1975, p. 28). Sob esse ponto de vista, os termos estão situados, enquanto tais, no plano da expressão.

O segundo postulado diz respeito ao lugar teórico reservado ao contínuo. Não é o caso de reacender uma querela sem objeto, pois a "casa do sentido" é vasta o bastante para acolher tanto o contínuo, quanto o descontínuo. O mais razoável é admiti-los como "variedades" circunstanciais e ocasionais. Mas, em nossa opinião, a pertinência deve ser atribuída à direção reconhecida, ou seja, à reciprocidade simultaneamente paradigmática e sintagmática do aumento e da diminuição. Diversas considerações sustentam essa idéia. Antes de mais nada, e sem fazer do isomorfismo dos dois planos uma religião, consideramos que o acento ocupa no plano da expressão uma posição tal que não se poderia conceber que ele deixasse de desempenhar qualquer papel no plano do conteúdo, e fazemos nossas as declarações de Cassirer quando este alude, em La philosophie des formes symboliques (Cassirer, 1985), ao "acento de sentido". Em segundo lugar, a semiótica, divergindo de sua escolha inicial, terminou por conceder ao aspecto um alcance extraordinário, muito além de sua aplicação ao processo: figuralmente falando, o aspecto 
é a análise do devir ascendente ou decadente de uma intensidade, fornecendo, aos olhos do observador atento, certos mais e certos menos. Essa abordagem é tributária, entre outros, de Gilles Deleuze, que por sua vez se confessava em débito com Kant, nesse particular. Em Francis Bacon, logique de la sensation, Deleuze supera a dualidade entre o paradigmático e o sintagmático: "A maioria dos autores que se viram confrontados a esse problema da intensidade na sensação parece ter encontrado esta mesma resposta: a diferença de intensidade se experimenta numa queda" (Deleuze, 1984, p. 54). Deleuze remete a um difícil trecho da Crítica da razão pura, intitulado "Antecipação da percepção", no qual Kant propõe que a sensação é uma "grandeza intensiva": "Toda sensação, e por conseguinte também toda realidade no fenômeno, por menor que seja, tem um grau, ou seja, uma grandeza intensiva, que pode ainda ser diminuída, e entre a realidade e a negação há uma série contínua de realidades e percepções possíveis cada vez menores [...]" (Kant, 1944, p. 194). Ressaltaremos que esse texto inter-relaciona duas categorias de primeira importância: (i) a direção, no caso decadente, o que equivale a dizer que a estesia se encaminha inexoravelmente para a anestesia, para aquilo que Kant chama "a negação =0"; (ii) a divisão em graus e, em seguida, a divisão desses próprios graus em partes de graus; o conceito de série - também presente em Brøndal, embora seus pressupostos sejam outros - pode ser considerado como um "sincretismo resolúvel" nessas duas categorias.

Essa presença irrecusável de Kant introduz na terminologia semiótica um nítido risco de distorção. Três pares de conceitos entram em interferência, do ponto de vista do significante: (i) o par [extenso versus intenso], ausente dos Prolegômenos, porém capital para se levar a efeito a reconciliação entre a morfologia e a sintaxe, uma das principais preocupações de Hjelmslev; (ii) o par [grandeza extensiva versus grandeza intensiva], exigido por Kant; (iii) o par [extensidade versus intensidade], que aparece, para nós, na análise da tensividade, e do qual ainda voltaremos a falar. Essa confluência terminológica conduz a mal-entendidos, caso os termos sejam dissociados de sua definição: (i) entre a abordagem kantiana e a perspectiva tensiva, a coincidência é bem-vinda, porém fortuita; (ii) entre as categorias 
hjelmslevianas e as categorias tensivas, surge um quiasmo, já que as categorias extensas são diretoras para Hjelmslev, quando, na perspectiva tensiva, a intensidade, ou seja, a afetividade, rege a extensidade; (iii) enfim, e salvo ignorância de nossa parte, Hjelmslev, ao falar de intenso e extenso, ou de intensivo e extensivo, ou ainda de intensional e extensional, não menciona o nome de Kant.

O terceiro postulado não se acha realmente no mesmo plano que os dois anteriores. Ele tem acesso ao campo de presença mediante catálise, mais do que por somação: como falar do devir, sem levar em consideração sua velocidade, seu andamento? $\mathrm{O}$ andamento é senhor, tanto de nossos pensamentos, quanto de nossos afetos, dado que ele controla despoticamente os aumentos e as diminuições constitutivas de nossas vivências. Não é, contudo, a existência do andamento que está em questão, e sim sua autoridade: como estabelecer os rudimentos de uma semiótica do acontecimento sem declarar a prevalência do andamento?

Dentro dos estreitos limites deste estudo, esses três dados mereceram nossa atenção, porque o sentido é tributário deles, sob diversos aspectos: a estrutura, porque formula; o devir, porque orienta; o andamento, porque dirige a duração do devir.

\section{Da tensividade às valências}

O estruturalismo privilegiou as microestruturas e negligenciou um dado, a nosso ver, da maior importância: a elasticidade do discurso, seja este verbal ou não-verbal. As relações de dependência estruturantes devem ser conjugadas, o que não é nada simples, com graus desiguais de extensão ou de campo; faremos, assim, uma distinção entre as estruturas amplas, que formam a rede, e as estruturas restritas a uma parte dela.

\subsection{Estruturas amplas}

Se as teorias progridem, é às avessas. Avançam a passos lentos na direção de suas premissas, ou, mais exatamente, na direção da explicitação de suas premissas. Não foi outro o procedimento da 
semiótica: ela precisou de bastante tempo para admitir a foria e a estesia, que a mede, como categorias diretoras de primeira ordem. Por isso, longe de apenas admitir, como que a contragosto, a afetividade, circunscrevendo-a à modesta função de adjunto adverbial de modo, preferimos acolhê-la, sob a denominação de intensidade, como grandeza regente do par derivado da esquizia inaugural:

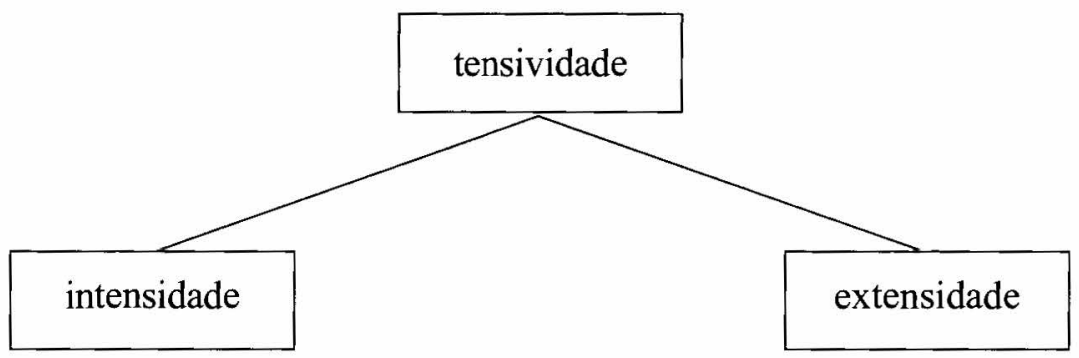

Essa bifurcação pede certas explicações: (i) a tensividade é o lugar imaginário em que a intensidade - ou seja, os estados de alma, o sensível - e a extensidade - isto é, os estados de coisas, o inteligível - unem-se uma a outra; (ii) essa junção indefectível define um espaço tensivo de recepção para as grandezas que têm acesso ao campo de presença: pelo próprio fato de sua imersão nesse espaço, toda grandeza discursiva vê-se qualificada em termos de intensidade e extensidade; (iii) em continuidade com o ensinamento de Hjelmslev, uma desigualdade criadora liga a extensidade à intensidade: os estados de coisas estão na dependência dos estados de alma; essa autoridade do sensível sobre o inteligível, já notória em nossa epígrafe, vem reforçada pela discussão que Cassirer, em La philosophie des formes symboliques, dedicou àquilo que ele chama "fenômeno de expressão"; as determinações intensivas e extensivas recebem aí a denominação, comum no campo das chamadas ciências humanas, de valências ${ }^{2}$;

2. Jacques Fontanille e Claude Zilberberg, Tensão e significação. Trad. Ivã Carlos Lopes, Luiz Tatit e Waldir Beividas. São Paulo, Discurso Editorial/Humanitas, 2001. Parece-nos, salvo melhor juízo, que tal acepção é obra de Cassirer. Assim, no tomo II de La philosophie des formes symboliques, pode-se ler: "Há diferenças de 'valências' próprias ao mito, do mesmo modo como há diferenças de valor para a lógica e a ética" (op. cit., p. 105); analogamente, no tomo III: "Essa transformação se dá quando diferentes significações - ou 'valências' são atribuidas aos diferentes momentos do devir fugaz" (op. cit., p. 178). 
de nossa parte, concebemos o valor como associação de uma valência intensiva com uma valência extensiva - associação cujo teor esclareceremos dentro de instantes.

O relevo emprestado à intensidade e à extensidade justificase por suas respectivas constituições: (i) a intensidade une o andamento e a tonicidade; (ii) a extensidade, a temporalidade e a espacialidade. A intensidade não é alheia à noção - para sempre obscura - de força, mas, como seu ser é um fazer, e provavelmente "nada além disso", como ela faz sentir seus efeitos, estes podem ser medidos em sua qualidade de subitaneidade, de "precipitação" e de energia; as qualidades, ilusórias enquanto qualidades, subsumem quantidades efetivas. A extensidade diz respeito à extensão do campo controlado pela intensidade, porém com uma ressalva: que a extensão desse campo é em primeiro lugar temporal, dado que o tempo humano, o tempo discursivo está sempre além do tempo. Quanto à terminologia, a intensidade e a extensidade assumem a posição de dimensões; o andamento e a tonicidade, por um lado, a temporalidade e a espacialidade, por outro, assumem a posição de subdimensões.

$\mathrm{A}$ atenção concedida por Saussure e seus seguidores à distintividade das unidades, assim como o abandono da retórica, abandono que dá a entender que "o domínio" retórico seria uma região provida de menor sentido, ocultaram o conteúdo das relações propriamente semióticas. É neste ponto que as premissas escolhidas mostram sua eficiência, e é aí, em especial, que a projeção da estrutura sobre as vivências ascendentes e decadentes levanta a seguinte questão: considerando que a estrutura é gramatical, como gramaticalizar essas vivências? Se, para a lingüística, a intensidade está "fora", "à margem" das coisas, para nós esta se acha no próprio cerne delas. $\mathrm{O}$ aumento pode ser obtido de duas maneiras: quer por meio de correlação conversa, do tipo "quanto mais... mais...", quer por meio de correlação inversa, do tipo "quanto mais... menos..." ou "quanto menos... mais...".

A projeção das coerções estruturais sobre esses "dados imediatos" leva a certos "teoremas" semióticos: 
(i) se a intensidade, como dimensão, rege a extensidade, tal controle mantém-se, em razão daquilo que Hjelmslev chamava "homogeneidade", entre as subdimensões pertencentes a dimensões distintas. $\mathrm{O}$ andamento rege a duração por uma correlação inversa, na medida em que a velocidade, para os homens, abrevia a duração do fazer: Quanto mais elevada é a velocidade, menos longa é a duração - apresentando-se o ser unicamente como um efeito peculiar à lentidão extrema. Por seu turno, a tonicidade rege a espacialidade; aliás, menos a espacialidade, na opinião de Deleuze, do que a profundidade, por uma correlação conversa: quanto mais forte é a tonicidade, mais vasto é seu campo de desdobramento.

(ii) entre as subdimensões pertencentes a uma mesma dimensão, a correlação é conversa, podendo ser pensada - por enquanto, mediante analogia - como um produto. Se as ditas ciências humanas afirmam, em coro, que o todo é superior à soma das partes, elas por outro lado se abstêm de explicar a proveniência desse suplemento pouco justificado e de dificil avaliação; sem querer enxergar, nos símbolos, mais do que comodidades de apresentação, propomos:

$$
[\mathrm{a}+\mathrm{b}]<[\mathrm{a} \times \mathrm{b}]
$$

Isso implica, para cada uma das dimensões em apreço:

(i) que o produto do andamento e da tonicidade tem por resultante necessária o impacto, o significado inapreciável de toda exclamação. Citaremos um único exemplo. No fragmento das Pensées referente à hierarquia das "três ordens", acerca de Arquimedes, Pascal escreve: “Arquimedes, sem causar impacto, teria a mesma veneração. Ele não ofertou batalhas para os olhos, mas forneceu a todos os espíritos suas invenções. $O$, que impacto para os espíritos!". A reciprocidade multiplicativa do andamento e da tonicidade é o fundamento plausível dos valores de impacto, ou seja, da superlatividade;

(ii) que o produto da maior extensão temporal e da maior extensão espacial tem por resultante necessária a universalidade, ou seja, 
aquilo que em outro estudo já chamamos valores de universo. (Zilberberg, 2001, p. 55-78). Cada qual em sua ordem, tais subdimensões funcionam como coeficientes.

A imprevisibilidade do sentido, que o identifica como algo a ser conhecido, e a factualidade que resulta disso estão vinculadas à questão "sempre recomeçada": entre os valores de impacto e os valores de universo, devemos supor uma correlação conversa ou uma correlação inversa? Se for uma correlação conversa, os valores de impacto e os valores de universo aumentam-se uns aos outros, $e$ tudo transcorre da melhor forma no melhor dos mundos possiveis...; se for uma correlação inversa, os valores de impacto diminuem proporcionalmente aos de sua extensão, de sua difusão. $\mathrm{O}$ debate designa, afinal, uma alternativa de grande envergadura: se as correlações conversas endossam, garantem a infinitude semiótica, as correlações inversas respeitam um - enigmático - princípio de constância, atribuindo alternadamente a cada grandeza, não mais uma função de multiplicador, como no caso das correlações conversas, e sim uma função de divisor, como se a correlação inversa estivesse submetida a um princípio de constância tal que, se uma das grandezas cresce, o correlato associado necessariamente decresce. Numa representação simples:

correlação conversa

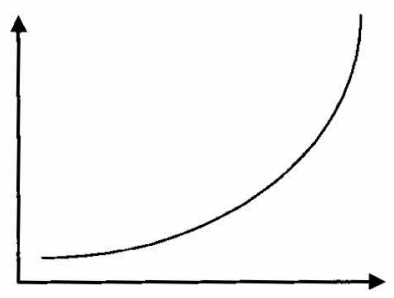

correlação inversa

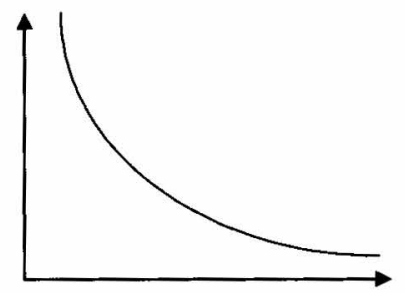

Essa bifurcação introduz-se como paradigma preliminar, dado que, independente das grandezas semânticas que processa (e talvez até indiferente a elas), convida os sujeitos a distinguir categoricamente entre o $\boldsymbol{e}$ da correlação conversa e o ou da correlação inversa. Se, sob o ponto de vista discursivo, cumpre "fazer uma idéia" das 
grandezas que permanecem no campo do discurso, já sob o ponto de vista metadiscursivo é importante saber se um determinado discurso declara uma compatibilidade ou uma incompatibilidade entre essas mesmas grandezas, como se o seu próprio ser dependesse apenas do espaço entre elas. Trata-se menos de penetrar no suposto âmago das coisas do que de responder à pergunta intransponível inventada por Saussure: alternância ou coexistência? Depois disso, como diz o poeta, tudo o mais é literatura...

\subsection{Estruturas restritas}

Cabe-nos agora articular as duas subdimensões intensivas, o andamento e a tonicidade, bem como as duas subdimensões extensivas, a temporalidade e a espacialidade, sobre uma mesma base formal que, sendo comum às quatro subdimensões aludidas, não é apanágio de nenhuma delas em particular; assim fazendo, evitamos privilegiar uma dada dimensão em detrimento das demais. As variações e vicissitudes de toda espécie que afetam o sentido decorrem de sua imersão no "movente" (Bergson), no instável e imprevisível, ou, em suma, de sua imersão na foria. A perenização dos clichês e a ritualização dos gêneros visam a conter e, por vezes, a estancar essa efervescência. Ao contemplarmos tais grandezas, que propomos designar como foremas, temos de explicitar, sem falseá-la - em outras palavras, sem imobilizá-la -, a foria cifrada, sob certo aspecto, por cada uma das quatro subdimensões mencionadas. A fim de qualificar em discurso um fazer que advenha em uma ou outra das subdimensões, é importante poder reconhecer sua direção, o intervalo assim percorrido e seu elã. Antes de prosseguir, assinalaremos ter encontrado, na feliz coincidência de uma leitura, a mesma tripartição em Binswanger: "A forma espacial com a qual lidávamos até o momento era, assim, caracterizada pela direção, pela posição e pelo movimento." (Binswanger, 1998, p. 79 , grifo nosso). Essa convergência não chega a surpreender, quando avaliamos a dívida de Merleau-Ponty para com os psicólogos e, em particular, para com Binswanger. Para nós, todavia, a questão não é operar - por indução - uma espacialização da significação, e sim efetuar uma semiotização do espaço. 
Como todo inventário, essa tripartição é cega. Em primeiro lugar, a direção e a posição são pressuponentes e o elã, pressuposto; adotamos o termo forema, a fim de indicar que as pressuponentes permanecem como tributárias de seu pressuposto. Essa primazia do elã está em concordância com dois outros dados: por um lado, a precedência do ser atingido sobre o agir e, por outro, a recção que postulamos da extensidade pela intensidade. Em segundo lugar mas já sob um outro aspecto: quando o agir se liberta da autoridade do ser atingido, apenas para satisfazê-lo, para agradá-lo -, é a direção que prevalece sobre a posição e o elã. Tocamos, assim, na questão do sujeito, desde que o pensemos em termos de deformação, acomodação, concordância.

$\mathrm{Na}$ perspectiva epistemológica stricto sensu, identificamos a valência como "interseção" de um forema com uma subdimensão. A propósito, se, como salienta Hjelmslev nos Prolegômenos, as "boas" definições são "divisões", é porque as grandezas semióticas no plano do conteúdo são complexas, mas essa complexidade é inerente a toda interseção. As características a priori das valências são justamente aquelas que lhes permitem circular, "comunicar-se", confrontar-se umas com as outras no discurso e, ao fazê-lo, promover o indispensável vaivém entre as localidades e a globalidade. Essa dupla lógica da complexidade e da interseção traz a seguinte conseqüência: o cruzamento metódico de três foremas com quatro subdimensões produz, em todas as acepções do termo, doze pares de valências:

3. Louis Hjelmslev, Prolegômenos a uma teoria da linguagem, op. cit., p. 74: "[O que] nos leva à definição da definição: por definição entendemos uma divisão seja do conteúdo de um signo, seja da expressão de um signo". 


\begin{tabular}{|c|c|c|c|c|}
\hline dimensões & \multicolumn{2}{|c|}{ intensidade regente } & \multicolumn{2}{|c|}{ extensidade regida } \\
\hline foremas & andamento & tonicidade & temporalidade & espacialidade \\
\hline direção & $\begin{array}{c}\text { aceleração } \\
\text { vs } \\
\text { desaceleração }\end{array}$ & $\begin{array}{c}\text { tonificação } \\
\text { vs } \\
\text { atonização }\end{array}$ & $\begin{array}{c}\text { foco } \\
v s \\
\text { apreensão }\end{array}$ & $\begin{array}{c}\text { abertura } \\
\text { vs } \\
\text { fechamento }\end{array}$ \\
\hline posição & $\begin{array}{c}\text { adiantamento } \\
\text { vs } \\
\text { retardamento }\end{array}$ & $\begin{array}{c}\text { superioridade } \\
\text { vs } \\
\text { inferioridade }\end{array}$ & $\begin{array}{c}\text { anterioridade } \\
\text { vs } \\
\text { posterioridade }\end{array}$ & $\begin{array}{c}\text { exterioridade } \\
\text { vs } \\
\text { interioridade }\end{array}$ \\
\hline elã & $\begin{array}{c}\text { rapidez } \\
\text { vs } \\
\text { lentidão }\end{array}$ & $\begin{array}{c}\text { tonicidade } \\
v s \\
\text { atonia }\end{array}$ & $\begin{array}{c}\text { brevidade } \\
v s \\
\text { longevidade }\end{array}$ & $\begin{array}{c}\text { deslocamento } \\
\text { vs } \\
\text { repouso }\end{array}$ \\
\hline
\end{tabular}

Descreveremos sumariamente as valências selecionadas para cada subdimensão. Para o andamento, a direção tem por dilema o par aceleração ou desaceleração. É comum ouvir dizer que nossa época está vivendo uma aceleração sem precedentes, por conta da precipitação das técnicas, mas, se esse fato é incontestável, sua explicação parece frágil, pois, conforme as análises de Wölfflin, a passagem da arte renascentista à arte barroca também se caracteriza, sem evolução técnica, por uma sensível aceleração; vale a mesma observação para certos períodos musicais. No que se refere à posição, as diferenças de andamento, os assincronismos produzem, do ponto de vista objetal, retardamentos e adiantamentos, e, do ponto de vista subjetal, precursores e retardatários, que fornecem aos historiadores algumas de suas categorias. Enfim, se considerarmos o elã, a aceleração do processo supõe, da parte do actante, uma vivacidade, uma energia que supere as resistências e os obstáculos.

Examinemos agora a tonicidade, termo que retomamos da prosódia, no plano da expressão, e da retórica tropológica, no do conteúdo. $\mathrm{O}$ dilema básico se dá entre a tonificação e a atonização. Tais denominações, por razões de eqüidade, são tomadas de empréstimo a Bachelard. À primeira delas corresponde a acentuação, a atribuição do inapreciável "acento de sentido" (Cassirer); à segunda, o enfraquecimento. Deixamos de lado, nesta súmula, a questão da ambivalência e da reversibilidade do crescimento e do decréscimo. 
Mesmo as quantidades negativas prestam-se ao aumento ou à diminuição: será que uma diminuição da tonicidade não é "mecanicamente" compensada por um aumento da atonia? Desse modo, a positividade diz respeito tanto ao crescimento quanto ao decréscimo e, por exemplo, no pensamento religioso hindu, o que faz sentido é, com o "princípio do nirvana", o crescimento da atonia. Aquilo que, para um ocidental em sua busca permanente de "divertimento", é um "vazio" insuportável, mostra-se nesse universo de discurso um "pico" desejável; analogamente, os chamados estados contemplativos são, para aqueles que os vivem, estados de plenitude. No que tange à posição, a tonificação e a atonização, em virtude dos mais e dos menos que suscitam fatalmente, são geradoras de diferenças orientadas; quando o ponto de vista, ou seja, o discurso, escolhe o mais do mais, falamos em superioridade, e falamos em inferioridade quando é o mais do menos que prevalece. Enfim, sob o aspecto do elã, a tonificação pede a garantia - fundo de reserva que permite a continuidade do fazer e sua antecipação - da tonicidade, do mesmo modo como a atonização remete à atonia, concebida como um "buraco negro" onde a energia viria perder-se e aniquilar-se.

Para o olhar tensivo, a temporalidade é uma categoria "como qualquer outra", isto é, analisável. Disso decorre um duplo distanciamento: (i) em primeiro lugar, por relação à palavra de ordem dos anos 1960, que estimava que "as estruturas eram acrônicas" e que a temporalidade não era senão um revestimento, uma concessão ao antropomorfismo; (ii) por relação a uma certa tradição filosófica tributária de Santo Agostinho, que sustentava: conheço o tempo se eu não pensar nele, mas ele me escapa se eu tentar pensálo...Nossa abordagem se pretende mais razoável: enquanto não for seriamente demonstrado que a temporalidade constitui uma exceção, uma singularidade, uma anomalia, admitiremos que os foremas determinam uma flexão temporal "nem pior nem melhor" que as três outras. $O$ forema da direção discrimina, de um lado, a apreensão, a retenção, a potencialização do advindo e, de outro lado, o foco, a protensão, a atualização do por-vir, ou ainda, nos termos de Valéry, a alternância recorrente entre o "já" e o "ainda não"; tais valências são "vivências de significação" (Cassirer) que se ordenam conforme 
relações de anterioridade e posterioridade, dando lugar a cronologias ora amplas, ora minuciosas. Como demonstrou Lévi-Strauss em sua polêmica com Sartre (Lévi-Strauss, 1962, p. 324-357), uma cronologia, sendo uma rede de malhas variáveis, cifra uma velocidade, um ritmo, uma textura; também nesse caso, parece desejável distinguir entre a forma científica, ligada à historiografia, e a forma semiótica, reservada à história, na qualidade de disciplina interpretativa. Com efeito, nem todas as anterioridades são significativas: elas são interrogativas, se ficar comprovado que ambos os acontecimentos em pauta pertencem realmente à mesma temporalidade. Sob esse aspecto, a psicanálise opta visivelmente por uma temporalidade contínua, na qual os "depois" continuam a depender estreitamente dos "antes", ou seja, do que ocorreu na primeira infância. Mas é a projeção do forema do elã que permite a apropriação prática, pragmática, da temporalidade pelos sujeitos: seguras, indubitáveis, a brevidade e a longevidade medem a duração e, à custa de certas convenções, mantêm-se sob nosso controle; é provável que, em matéria de tempo, jamais venhamos a fixar verdades definitivas, porém essa ignorância não nos pesa, permanecendo alheia ao uso, ao "emprego" do tempo, tal como este sobressai na espera, na paciência ou na impaciência, essas paixões comuns do tempo.

Talvez por desfrutar do primado em nosso próprio universo de discurso, a espacialidade é mais bem recebida. O que o forema da direção distingue não são propriamente orientações geográficas, e sim aquilo que estaria aquém de tais orientações, a saber, a tensão entre o aberto e ofechado, que permite ao sujeito formular programas elementares, por um lado, de entrada ou penetração e, por outro, de saída ou escape, em função da tonicidade ambiente. Partindo dos textos dos escritores, principalmente dos poetas - esses geógrafos do imaginário -, Bachelard disse tudo o que se podia dizer a respeito, em especial na Poética do espaço (Bachelard, 1981, p. 191-207). As figuras do aberto e do fechado acham-se numa relação de assimetria: é a presença de, no mínimo, um fechado, um bolsão, uma oclusão, que estabelece o aberto como tal. Analogamente, o forema de posição, discriminando o interior e o exterior, pressupõe "em algum lugar" a existência de um fechado. Assim como na 
temporalidade, a questão é determinar se duas grandezas pertencem ou não ao mesmo espaço. O forema do elã resulta no contraste entre o repouso e o movimento, entre o lugar e o deslocamento, estigmatizado por Baudelaire em "Les hiboux". Esse forema é o sincretismo resolúvel da potência e da inércia, a arena mental onde uma mede forças com a outra.

Essas valências são funções, funcionamentos, na medida em que se trata de termos para o significante, e de complexos para o significado; são gramaticais, em sentido estrito, dado que são interseções homólogas às propostas pelas gramáticas. Assim, em francês, o pronome adjetivo possessivo son é, quanto ao possuidor, uma terceira pessoa $\mathrm{e}$, quanto à coisa possuída, um masculino singular. A formalidade das subvalências é da mesma ordem, apenas com um grau de sofisticação suplementar, talvez: a subvalência de repouso tem como "harmônicos", como subvalências de fundo a longevidade (ou, se se preferir, a permanência), a atonia e, enfim, a lentidão paroxística da parada. Em suma, as subvalências surgiriam juntas, mais de acordo com o modelo da sinfonia do que com o da sonata. Lembrando Claudel, injustamente incompreendido enquanto semioticista:

Uma só coçadela com a unha e o sino de Nara põe-se a retinir e ressoar. [...] E a alma inteira se comove nas profundezas superpostas de sua inteligência. (Claudel, 1965, p. 73)

Uma das funções do léxico consiste, observada essa solidariedade estrutural, em permitir a seleção daquela dentre as subvalências que esteja em conformidade com o topos desenvolvido pelo discurso. Tal profundidade valencial não está ausente das línguas, por pouco que atentemos para o fato. Assim, em francês, o artigo indefinido e o definido opõem-se também, e talvez sobretudo, como o interveniente se opõe ao intervindo, se levarmos em conta sua ordem canônica de aparecimento no discurso; entretanto, considerando-se que a dimensão do intervir ${ }^{4}$ ainda não teve sua pertinência

4. [N. dos T.] No original, survenir [sobrevir]. Optamos circunstancialmente pelo verbo intervir, em razão de sua maior flexibilidade morfológica em português. 
reconhecida, esse esboço de declinação tensiva permanece sem efeito.

A rede proposta atribui a cada subvalência um endereço, mas a colocação em rede está no princípio de duas outras propriedades estruturais: (i) a recção das subdimensões pelo mesmo forema é homogeneizante, a exemplo do que ocorre na língua francesa, em que a série dé-faire, dé-coudre, dé-tacher, dé-composer, décharger etc. atrai para si todo termo que comporte a idéia de "afastamento, separação, privação de um estado ou de uma ação" (Grand Robert), ainda que, como no caso de déchirer, a sílaba dénão remonte ao prefixo latino des-. No Curso de lingüística geral, Saussure demonstrou, acerca das "relações associativas", que a língua, nesse particular, era bastante pródiga; (ii) a comutação dos foremas, para uma mesma subdimensão, é diferenciadora e, em última instância, comparável a uma análise espectral: em função do forema selecionado, a subdimensão muda de construção, ou ainda de aspecto, na acepção genérica do termo.

\section{Fisionomia das estruturas elementares}

Se excetuarmos a psicanálise, o Valéry dos Cahiers, os capítulos que Cassirer dedica ao "fenômeno da expressão" na Filosofia das formas simbólicas, além, é claro, de Nietzsche e mais uns poucos autores, a afetividade costuma ser considerada, ora negligenciável, na opinião de alguns, ora embaraçosa, na opinião de outros mais clarividentes - como se a pergunta "mas como abordála?" já esgotasse a problemática. A “desretorização" da lingüística foi conduzida na mesma direção. Não faltam monografias penetrantes acerca deste ou daquele afeto, de tal ou qual paixão, porém uma analítica a priori do sensível, em ressonância com as aquisições da semiótica, ainda está por construir. Não temos em absoluto a pretensão de dar aqui a última palavra no assunto, mas somente de expor categorias que, a nosso ver, uma análise bem fundamentada do afeto tem de levar em conta, combinando-as com a rede de doze pares de 
subvalências que acabamos de apresentar, já que as valências são formas no plano da expressão e afetos no plano do conteúdo ${ }^{5}$.

\subsection{Analítica do sensivel}

O primeiro ponto que ressaltaremos é um lembrete: o estruturalismo permaneceu enredado nos termos, sem conceber as propriedades da relação enquanto tais. Já tivemos ocasião de mencionar dois pontos: em primeiro lugar, os termos são definíveis; eles o são por serem complexos, por serem resultantes - verificaremos mais abaixo - de uma interseção bi- ou multidimensional. Cumpre agora ir mais além e formular os rudimentos de uma semiótica do intervalo. A diferença saussuriana, como se isso fosse óbvio, foi pensada ou repensada em termos de contrariedade e contradição, mas nem todos os contrários se equivalem, se nos lembrarmos de Bachelard: "[...] podem ser evocados dois tipos de casos, conforme os contrários se ergam numa hostilidade decisiva ou estejamos diante de contrariedades mínimas". ${ }^{6}$ Distinguiremos entre os sobrecontrários tônicos e distantes, e os subcontrários átonos e próximos, vinculando-se a tonicidade ao plano do conteúdo e a distância, ao plano da expressão. Algumas convenções terminológicas se fazem necessárias para a leveza de nossa explanação. Seja um gradiente que vai de $\left[\mathrm{s}_{1}\right]$ até $\left[\mathrm{s}_{4}\right]$, observando uma pausa em $\left[\mathrm{s}_{2}\right] \mathrm{e}$ depois em $\left[\mathrm{s}_{3}\right]$. Os termos $\left[\mathrm{s}_{1}\right]$ e $\left[\mathrm{s}_{4}\right]$ surgem como sobrecontrários, e $\left[\mathrm{s}_{2}\right]$ e $\left[\mathrm{s}_{3}\right]$, como subcontrários (Sapir):

\begin{tabular}{|c|c|c|c|}
\hline $\mathrm{s}_{1}$ & $\mathrm{~s}_{2}$ & $\mathrm{~s}_{3}$ & $\mathrm{~s}_{4}$ \\
\hline sobrecontrário & subcontrário & subcontrário & sobrecontrário \\
\hline
\end{tabular}

5. [N. dos T.] Neste ponto, como em outras ocorrências ao longo deste artigo, o emprego das expressões "plano da expressão" e "plano do conteúdo" não se identifica com a célebre dicotomia saussuriana "significante/significado". Devemos compreendê-las por referência às noções respectivas de "manifestante" e "manifestada" (Hjelmslev).

6. Gaston Bachelard, La dialectique de la durée [1936], Paris, Presses Universitaires de France, 1993, p.144; na página seguinte, Bachelard se refere a "contrários [...] menos distantes, menos hostis". 
De acordo com a herança hjelmsleviana, essa estrutura é uma estrutura mínima, visto que $\left[\mathrm{s}_{1}\right]$ e $\left[\mathrm{s}_{4}\right]$ se opõem a $\left[\mathrm{s}_{2}\right]$ e $\left[\mathrm{s}_{3}\right]$, mas também se opõem entre si. Contudo, o essencial, sob a perspectiva de uma semiótica do intervalo, não está aí. Dispomos de dois intervalos bem definidos, em termos de tensividade: o intervalo maior $\left[s_{1} \Leftrightarrow s_{4}\right]$ e o intervalo menor $\left[s_{2} \Leftrightarrow s_{3}\right]$. Uma objeção, legítima em aparência, deve ser neste ponto afastada: por que privilegiar esses dois intervalos, ao invés de $\left[\mathrm{s}_{1} \Leftrightarrow \mathrm{s}_{2}\right]$ e $\left[\mathrm{s}_{3} \Leftrightarrow \mathrm{s}_{4}\right]$ ? Para além de sua "aversão" mútua, os extremos $\left[\mathrm{s}_{1}\right]$ e $\left[\mathrm{s}_{4}\right]$ estariam ligados por uma solidariedade procedente de sua comum "abjeção" para com os termos medianos $\left[\mathrm{s}_{2}\right]$ e $\left[\mathrm{s}_{3}\right]$. Tal é a hipótese de Gœthe, no Tratado das cores: "O olho não pode, nem quer manter-se um só instante no estado uniforme especificamente determinado pelo objeto. Algo como uma tendência ao antagonismo o condiciona; opondo o extremo ao extremo, o intermediário ao intermediário, ela reúne instantaneamente os contrários e tenta constituir uma totalidade, tanto no caso dos fenômenos que se sucedem, quanto no dos que coexistem no tempo ou no espaço" (Gœthe, 2000, p. 104). Essa estrutura mínima não deixa, além disso, de exibir semelhanças com o quarteto de rimas interpoladas "à francesa", que faz rimarem entre si, de um lado, os versos externos e, de outro, os versos internos. Uma vez que a semiose é onipresente, a seqüência $\left[s_{1}-s_{2}-s_{3}-s_{4}\right]$ pode ser tomada como plano da expressão e a alternância $\left[\left[\mathrm{s}_{1} \Leftrightarrow \mathrm{s}_{2}\right]\right.$ vs $\left.\left[\mathrm{s}_{3} \Leftrightarrow \mathrm{s}_{4}\right]\right]$, como plano do conteúdo. ${ }^{7}$ Ao dispor os elementos dessa maneira, não estamos sacrificando a complexidade: se uma análise selecionar $\boldsymbol{n}$ termos, o número de termos complexos realizáveis terá uma unidade a menos $[n-1]$, fornecendo os seguintes possíveis: $\left[\mathrm{s}_{1}+\mathrm{s}_{2}\right]$, $\left[\mathrm{s}_{2}+\right.$ $\left.\mathrm{s}_{3}\right]$ e $\left[\mathrm{s}_{3}+\mathrm{s}_{4}\right]$.

A única coisa que pedimos a esse dispositivo é a desigualdade entre os dois intervalos indicados, ou seja, que o intervalo entre os subcontrários $\left[\mathrm{s}_{2} \Leftrightarrow \mathrm{s}_{3}\right]$ esteja contido dentro do intervalo entre os sobrecontrários $\left[\mathrm{s}_{1} \Leftrightarrow \mathrm{s}_{4}\right]$, pois deduziremos, dessa desigualdade elementar, duas formas-afeto notáveis: (i) a falta não é nada mais

7. [N. dos T.] Cf. nota 14. 
que o resultado da projeção do intervalo $\left[\mathrm{s}_{1} \Leftrightarrow \mathrm{s}_{4}\right]$ sobre o intervalo $\left[\mathrm{s}_{2} \Leftrightarrow \mathrm{s}_{3}\right]$; (ii) inversamente, o excesso não é nada mais que o resultado da projeção do intervalo $\left[\mathrm{s}_{2} \Leftrightarrow \mathrm{s}_{3}\right]$ sobre o intervalo $\left[\mathrm{s}_{1} \Leftrightarrow\right.$ $\left.\mathrm{s}_{4}\right]$. Em outras palavras, cada intervalo tem um duplo funcionamento, alternadamente como termo regido e como função regente, ora como avaliado, ora como avaliante. Disso decorrem várias conseqüências. A falta, central para a psicanálise e a narratologia greimasiana, deixa de ser uma grandeza órfã, recebendo, de direito, seu correlato paradigmático, o excesso, cuja discursivização se acha, de Longino a Michaux, no cerne da retórica, sob a denominação de sublime. Do ângulo teórico, somos postos subitamente perante aquilo que se deveria chamar, por referência ao ensinamento de Greimas, de ilusão sêmica. Ainda que a fenomenologia e a psicologia da percepção não nos apontassem tal caminho, os semas deveriam ser concebidos como significantes cômodos - pois não é fato que compartilham sua rusticidade, sua robustez? -, mas não como significados; no plano do conteúdo, nada haveria senão pontos de vista provisórios, operações de projeção, aplicações, reciprocidades de perspectiva... além de ilusões. A epistemologia da semiótica terá certamente de se adaptar, de erradicar o positivismo renascente, dado que essas catálises não recaem sobre grandezas, e sim sobre operações relativamente inéditas. A força da palavra de ordem de Saussure ("a língua é uma forma e não uma substância") permanece intacta.

A esse primeiro jogo de intervalos, que fornece para cada valência uma identidade inequívoca, cumpre acrescentar uma característica que se ajusta a nosso segundo postulado - pelo qual um devir se processa necessariamente, "cedo ou tarde", por aumento ou diminuição, por ascendência ou decadência. Com efeito, se tivéssemos de imaginá-las, as valências seriam menos unidades, porções de uma linha, do que vetores: antes particípios presentes que particípios passados. As valências são seqüências de processos. As categorias aspectuais de que dispomos dizem respeito ao estágio de desenvolvimento do processo, mas nada acrescentam sobre sua orientação tensiva, ascendente ou decadente. A aspectualidade lingüística, aliás, é duplamente restritiva: (i) ela privilegia o verbo, negligenciando o notável trabalho de análise convertido nas demais 
regiões do léxico; (ii) em sua versão restrita, ela se prende ao grau de acabamento ou inacabamento do processo, e a incoatividade só aparece com a tripartição.

As condições a serem satisfeitas são simples: (i) a aspectualidade tem de estar repartida eqüitativamente pelo conjunto do devir, ou seja, tem de estar em condições de caracterizar "conforme a encomenda" todo e qualquer momento desse devir; (ii) ela deve respeitar a insuperável ambivalência do sentido, como por exemplo o fato de que a tonicidade crescente também pode ser descrita como uma atonia decrescente, do mesmo modo como uma atonia crescente também pode ser expressa em termos de uma tonicidade decrescente. Nesse sentido, propusemos em outro estudo um jogo de categorias aspectuais com as seguintes características: (i) são mais tributárias da retórica, do espírito da retórica, do que da lingüística, o que é conseqüente, dado que a retórica tem por objeto o discurso, e até mesmo a veemência do discurso, o qual ainda permanece além do alcance da lingüística, que, pusilânime, se limita à frase; (ii) essas categorias aspectuais são gerais, isto é, independentes de qualquer conteúdo, aplicando-se por isso mesmo, e a exemplo do número, a todas as grandezas, já que nenhuma grandeza pode ter realmente a pretensão de escapar ao devir.

Uma vez explorada a desigualdade capital dos intervalos "homotéticos" [ $\left.\mathrm{s}_{1} \Leftrightarrow \mathrm{s}_{4}\right]$ e $\left[\mathrm{s}_{2} \Leftrightarrow \mathrm{s}_{3}\right]$, cabe-nos agora considerar os sucessivos intervalos que permitem situar o devir ascendente ou decadente de uma dada valência em discurso, o que equivalerá a explicar o que se passa quando uma determinada valência "sai" do intervalo $\left[s_{1} \Leftrightarrow s_{4}\right.$ ] e "entra" no intervalo [ $s_{2} \Leftrightarrow s_{3}$ ], e vice-versa. É certo que estamos intervindo de maneira "arbitrária", para usar o termo escolhido por Hjelmslev nos Prolegômenos, porém acreditamos, de boa fé, estar adotando a mais simples das convenções:

(i) dado $\left[\mathrm{s}_{1}\right]$ como valência paroxística, designamos, a fim de opor a decadência a si própria, o intervalo $\left[\mathrm{s}_{1}+\mathrm{s}_{2}\right]$ como atenuação e o intervalo $\left[\mathrm{s}_{3}+\mathrm{s}_{4}\right]$ como minimização. Por recursividade, devemos alcançar o "infinito de pequenez" caro a Pascal;

(ii) dado $\left[\mathrm{s}_{4}\right]$ como valência nula, tal nulidade reclama sua denegação ou, em outras palavras, a travessia do intervalo $\left[\mathrm{s}_{4}+\mathrm{s}_{3}\right]$, que 
designamos como um restabelecimento, que disjunta do "nãoser", isto é, do tédio. O discurso pode, decerto, ater-se a isso, mas também pode perfeitamente "estender-se" para além de $\left[\mathrm{s}_{3}\right]$ : diremos então que, ao restabelecimento, sucede a exacerbação, alojada no intervalo $\left[\mathrm{s}_{1}+\mathrm{s}_{2}\right]$.

Essas categorias interdefinidas inspiram-se sobretudo na retórica e na poética; a poética de Rimbaud, por exemplo, é, em seus momentos culminantes, uma poética do restabelecimento e da exacerbação. Contudo, tornamos a repetir: a retórica "sente" melhor as singularidades do discurso do que a lingüística. Apenas para fixar as idéias, na análise exemplar dos "Chats" de Baudelaire empreendida por Jakobson e Lévi-Strauss (Jakobson \& Lévi-Strauss, 1973, p. 401429), não se pode negar que "o" lingüístico serve - tão-somente! de plano da expressão, enquanto "o" retórico serve de plano do conteúdo ${ }^{8}$ especialmente no final. Portanto:

\begin{tabular}{|c|c|}
\hline $\begin{array}{c}\text { decadência } \\
{\left[\mathrm{s}_{1} \Leftrightarrow \mathrm{s}_{14}\right]}\end{array}$ & $\begin{array}{c}\text { atenuação } \approx \text { de } \mathrm{s}_{1} \text { a } \mathrm{s}_{2} \\
\text { minimizaçãot } \approx \text { de } \mathrm{s}_{3} \mathrm{a} \mathrm{s}_{4}\end{array}$ \\
\hline $\begin{array}{c}\text { ascendência } \\
{\left[\mathrm{s}_{4} \Leftrightarrow \mathrm{s}_{1}\right]}\end{array}$ & $\begin{array}{c}\text { restabelecimento } \approx \text { de } \mathrm{s}_{4} \text { a } \mathrm{s}_{3} \\
\text { exacerbação } \approx \text { de } \mathrm{s}_{2} \mathrm{a} \mathrm{s}_{1}\end{array}$ \\
\hline
\end{tabular}

Em razão dos limites estreitos deste ensaio, não vamos discutir aqui os demais derivados, que unem, para ambas as orientações, ora um limite e um grau: $\left[\mathrm{s}_{1} \Leftrightarrow \mathrm{s}_{2}\right.$ ], ora dois graus: $\left[\mathrm{s}_{2} \Leftrightarrow \mathrm{s}_{3}\right.$ ], ou enfim um grau e um limite: [ $s_{3} \Leftrightarrow s_{4}$ ]. A integração do paradigma (ou seja, da morfologia própria à contrariedade) com a sintaxe tensiva dos devires acaba por assumir a seguinte forma:

8. [N. dos T.] Cf. nota 14. 


\begin{tabular}{|c|c|c|c|}
\hline $\mathrm{s}_{1}$ & $\mathrm{~s}_{2}$ & $\mathrm{~s}_{3}$ & $\mathrm{~s}_{4}$ \\
\hline sobrecontrário & subcontrário & subcontrário & sobrecontrário \\
\hline \multicolumn{2}{|c|}{ atenuação } & & $\longrightarrow$ \\
\hline \multicolumn{2}{|c|}{ exacerbação } & \\
\hline
\end{tabular}

As categorias aspectuais garantem a homogeneidade do sistema, visto que as propriedades gerais deste último - a saber, por um lado a orientação ascendente ou decadente e, por outro, a "analisabilidade" - são convertidas em foremas locais, atribuindo a cada subvalência uma direção tensiva e uma identidade segura.

\subsection{Declinação das subdimensões}

A lógica da "interseção" e da rede leva-nos a determinar cada forema admitido por cada uma das quatro categorias aspectuais, e também a conceber o produto dessa recção como uma subvalência, pois que está ligado a uma subdimensão; dado o caráter movente, instável e provisório do universo do sentido, é importante nomear, porque as denominações funcionam, por um lado, como paradas, amarras, e, por outro, como uma moeda de troca para os sujeitos. As denominações propostas são apenas toleráveis - logo, perfectíveis e talvez tributárias de uma pancronia que, segundo Hölderlin, Brøndal e alguns outros autores, sempre sob aspectos diversos, naturalmente, alteraria a justeza do equilíbrio entre a expressão da intensidade e a da extensidade; ao fazê-lo, essa pancronia encaminharia as línguas para uma ressecante abstração simbólica. Mas não é o que nos interessa, no presente ensaio.

O cruzamento mental de três foremas com quatro categorias aspectuais elementares produz mecanicamente doze subvalências para cada dimensão. Independentemente de um exame mais aturado, reproduzimo-las em seguida: 
$\mathrm{O}$ andamento:

\begin{tabular}{|l|c|c|c|c|}
\hline foremas & minimização & atenuação & restabelecimento & exacerbação \\
\hline direção & $\begin{array}{c}\text { "traîner" } \\
\text { [ir muito lenta- } \\
\text { mente] }\end{array}$ & desaceleração & aceleração & precipitação \\
\hline posição & anacronismo & atraso & adiantamento & prematuridade \\
\hline elã & inércia & lentidão & rapidez & vivacidade \\
\hline
\end{tabular}

A tonicidade:

\begin{tabular}{|l|c|c|c|c|}
\hline foremas & minimização & atenuação & restabelecimento & exacerbação \\
\hline direção & extenuação & atonização & tonificação & avultação \\
\hline posição & nulo & inferior & superior & excessivo \\
\hline elã & estado & repouso & movimento & ataque \\
\hline
\end{tabular}

A temporalidade:

\begin{tabular}{|l|c|c|c|c|}
\hline foremas & minimização & atenuação & restabelecimento & exacerbação \\
\hline direção & retrospecção & apreensão & foco & antecipação \\
\hline posição & obsoleto & anterior & posterior & imortal \\
\hline elã & efêmero & breve & longo & eterno \\
\hline
\end{tabular}

9. [N. dos T.] Em português: "arrastar-se". Conservamos o termo original, cujas acepções serão especialmente tratadas nos parágrafos subseqüentes. 
A espacialidade:

\begin{tabular}{|l|c|c|c|l|}
\hline foremas & minimização & atenuação & restabelecimento & exacerbação \\
\hline direção & hemértico & fechado & aberto & escancarado \\
\hline posição & estranho & exterior & interior & íntimo \\
\hline elã & fixidez & repouso & deslocamento & ubiqüidade \\
\hline
\end{tabular}

Como podemos validar o conteúdo semiótico de tais grandezas que, por seu duplo estatuto de lexemas e de figuras, estão a meio caminho da lingüística e da retórica? Jakobson mostrou que a função metalingüística não era apanágio dos doutos, mas, pelo contrário, era imanente à prática imediata da língua, e que os sujeitos recorriam à definição, à restrição ou à extensão, à precisão ou à suspensão, porém parece ter deixado de mencionar a condição objetal dessa recorrente atividade metalingüística. Para nós, ela reside no seguinte fato: os lexemas dependem de uma definição, por serem analisáveis, e eles são analisáveis por serem tudo o que podem ser; em outras palavras, não são nada além de... análises reservadas a um significante, por sua vez, não-conforme. Assim é que o significado do pronome pessoal $/ t u /$, em português, compreende três grandezas de conteúdo: uma indicação de número, uma de pessoa e uma de nominativo, mas as duas grandezas da expressão $[\mathrm{t}-\mathrm{u}]$ não remetem "analiticamente" às três grandezas do conteúdo. Não é outro o funcionamento dos lexemas, e as definições dos dicionários, sem dúvida complicadas pelo número de grandezas a processar, analisam intuitivamente - e pertinentemente - os lexemas, com a ajuda das subvalências, embora procedendo, por assim dizer, caso a caso. Examinaremos aqui um único exemplo, a primeira subvalência da primeira rede: fr. "traîner", cuja denominação não pode escapar a certas críticas, já que falta o substantivo correspondente, lacuna atribuível, quer a nossas insuficiências, quer àquilo que Mallarmé chamava de imperfeição das línguas. Enfim, o Micro-Robert propõe ainda - quase diríamos: poeticamente - "traînasser" [vagabundear] e "traînailler" [vadiar], aos quais retornaremos dentro de instantes. 
O sentido intransitivo de "traîner" admite, segundo o MicroRobert, as quatro direções tensivas previstas. Quanto à intensidade: (i) uma indicação de andamento, correspondente, no caso, à minimização da velocidade $\mathrm{e}^{10}$ : " 6 ' Ir com demasiada lentidão, demorar. Não demore para voltar da escola. Agir com demasiada lentidão. $O$ trabalho urge. Não podemos mais demorar"; (ii) uma indicação de tonicidade decadente, sem que possamos especificar se se trata da atenuação ou da minimização: " $7^{\circ}$ Ir sem rumo ou permanecer por muito tempo (em um lugar pouco recomendável ou pouco interessante). V. Vagar, vagabundear. Perambular pelas ruas. Quanto à extensidade: (i) uma indicação temporal de comprimento, de duração, sob o signo da exacerbação: "30 Achar-se, subsistir. $A s$ velhas noções que perduram nos livros escolares. $4^{\circ}$ Durar além da conta, não acabar nunca. Isso já está durando demais. V. Eternizar."; (ii) uma indicação espacial de repouso: "1 (Sujeito: Coisa) Pender sobre o chão, arrastando-se. Seus cadarços estão se arrastando pelo chão. $2^{\circ}$ Estar disposto ou ter sido abandonado, em desordem. Roupas largadas sobre uma cadeira". A coerência e a flexibilidade da rede resolvem a divergência das "variedades". A propósito dessas considerações preliminares, é compreensível que Valéry tenha escrito, sem que saibamos se por satisfação ou por lástima: "Tudo está predito pelo dicionário" (Valéry, 1973, p. 394). Dentro dos limites deste breve ensaio, fizemos questão de mostrar que o modelo valencial comparecia, imanente, eficiente e sugestivo, mas está claro que as definições citadas são portadoras de outras grandezas de conteúdo, umas actanciais e actoriais, outras axiológicas, como a oposição entre "a rua" e "a escola"... Os dois derivados pejorativos "traînasser" e "traînailler" não se acham excluídos do sistema; muito pelo contrário, estão no seu próprio cerne, já que recaem sobre a subvalência de andamento e denunciam, pela convocação do advérbio trop [demasiado(a)], um subcontrário como um sobrecontrário. Assinalemos que, sob o prisma tensivo, não temos

10. [N. dos T.] Os números ordinais deste parágrafo correspondem às acepções do verbete traîner no dicionário Micro-Robert. Destacamos em negrito todas as traduções portuguesas para o verbo traîner em seus diferentes contextos.

Significação $25 \cdot 188$ 
com isso nada mais que um inventário, pois o modelo valencial enfatiza, em princípio, uma dupla sobredeterminação: a da temporalidade pelo andamento e a da espacialidade pela tonicidade. O Micro-Robert efetua tacitamente essa operação, ao associar - talvez considerando que a coisa é evidente - "ir com demasiada lentidão" e "demorar", como se a lentidão excessiva no plano do conteúdo tivesse como plano de expressão ${ }^{11}$ o atraso, confirmando, no mesmo gesto, que a semiose é ininterrupta.

\section{A sintaxe discursiva}

Por mais amplas que sejam as inflexões ocorridas, a epistemologia da semiótica permanece, em grande medida, tributária do ensinamento de Hjelmslev. Debateremos em particular dois pontos: a relação entre o sistema e o processo, que faz parte dos "cinco traços fundamentais [...] da estrutura fundamental de toda língua", e o projeto declarado de "abalar a base da bifurcação tradicional da lingüística em morfologia e sintaxe" (Hjelmslev, 1975, p. 75). Surge uma tensão entre essas duas direções epistemológicas: por um lado, consolidar a distinção entre o sistema e o processo; por outro, reduzila. Sem entrar nos pormenores requeridos, temos a impressão de que os atores responsáveis por essas providências não são bem os mesmos, na medida em que o teórico "Hjelmslev" assumiria a primeira, enquanto o lingüista "Hjelmslev", a segunda. Nem por isso deixa de ser verdade que as duas exigências não se situam no mesmo plano e que a moderação de uma distinção pressupõe seu reconhecimento. A mediação entre a morfologia e a sintaxe será buscada em primeiro lugar para a intensidade e, em seguida, para a extensidade.

\subsection{A sintaxe intensiva}

Discorrendo sobre a definição semiótica do objeto, Greimas insiste na "ausência de qualquer determinação prévia do objeto, que

11 [N. dos T.] Cf. nota 14. 
não seja sua relação com o sujeito" (Greimas \& Courtés, s/d [1983], p. 313). Pode-se dizer o mesmo também, ou até em primeiro lugar, a propósito do afeto e da valência que o identifica, sob o ponto de vista cognitivo, e que o mede, sob o ponto de vista tímico: realmente, como poderíamos admitir que aquilo que afeta, comove o sujeito irrompendo, em geral, de forma inesperada - não se instalasse, de direito, no centro do campo discursivo?

Em conformidade com nosso segundo postulado, que modaliza o contínuo como ascendente ou decadente, já registramos, quanto ao sistema, a alternativa do aumento ou da diminuição; mas o que se passa com esses primitivos no processo? Segundo Hjelmslev, as relações próprias ao sistema são da ordem do "ou... ou..." e as relações peculiares ao processo, da ordem do "e... e...", de tal sorte que o processo aproxima, pelos seus próprios meios, aquilo que o sistema afasta na sua ordem. Isso posto, podemos introduzir a hipótese referente à inflexão tensiva da sintaxe: os termos do paradigma básico vão-se tornando alternadamente objetos uns para os outros. Em outras palavras, um aumento tem por objeto interno uma diminuição, do mesmo modo como uma diminuição tem por objeto interno um aumento. Esse entrelaçamento fornece à sintaxe intensiva razão e necessidade, marcando-a com a modalidade do precaver ou do prover, conforme o caso: se a diminuição for provável, o sujeito terá de precaver-se contra ela; se ela já estiver em curso, então ele tratará de reparar o dano que vai ganhando amplitude.

Quanto ao plano da expressão - no caso da tonicidade, mais fácil de se formular - poderiamos nos contentar em afirmar que a sintaxe intensiva cultiva em ascendência a hipérbole, mas a observação atenta dos grandes discursos mostra que tal abordagem tem algo de míope, por não apreender o trabalho de solapamento operado por uma negatividade eficiente, cuja necessidade foi analisada por Deleuze em Différence et répétition (Deleuze, 1989). Se, no que diz respeito ao foco, a hipérbole aumenta e amplifica, é porque ela apreende o baixo contínuo da decadência.

Esse entrelaçamento está na primeira ordem de derivados da ascendência e da decadência. Com efeito, as categorias aspectuais são emparelhadas de duas em duas: (i) a atenuação e a exacerbação; 
(ii) a minimização e o restabelecimento. Uma estrutura pode, por outro lado, aplicar a transitividade ou a reflexividade. O primeiro caso acaba por projetar quatro sintagmas elementares que darão muito que pensar ao discurso. Na decadência: (i) uma atenuação tem como objeto (não de busca, e sim de recusa, quando não de refugo) uma exacerbação. Ela vem abrandar o pico de intensidade visado pela exacerbação; (ii) a minimização promove o retorno à nulidade, ao paroxismo de atonia que o restabelecimento havia superado. De maneira simétrica e inversa, teremos na ascendência: (i) o restabelecimento combate a minimização; (ii) a exacerbação batese contra uma atenuação que ela tenta reduzir, a fim de restituir o lustre e o impacto da tonicidade. Quanto à reflexividade, o sujeito tanto pode incrementar um restabelecimento até a exacerbação - ou seja, aumentar um aumento -, quanto abaixar uma atenuação até a minimização, isto é, acentuar ainda mais uma diminuição.

Isso tudo é confirmado por um depoimento de Cézanne: "No meu caso, a realização das sensações é sempre muito penosa. Não consigo alcançar a intensidade que se oferece aos meus sentidos, não tenho essa magnífica riqueza de coloração que anima a natureza". ${ }^{12}$ A observação de Cézanne estabelece um paroxismo: "essa magnífica riqueza de coloração que anima a natureza", que funciona como um emissor e se transmite sem enfraquecimento, num primeiro instante, a um receptor sensivel: "a intensidade que se oferece aos meus sentidos". Tal "intensidade" potencializada sofre um processo de atenuação que reclama, da parte de Cézanne, uma exacerbação sobre cujo êxito ele se mostra cético: "Não consigo alcançar...". Nesse sentido, pode-se dizer que a inquietude está no cerne de toda poética exigente.

12. Carta (13 de outubro de 1906) a seu filho, em Paul Cézanne, Correspondance, recueillie, annotée et préfacée par John Rewald, Paris, Grasset, 1978, p. 324; citada por Lawrence Gowing, Cézanne. La logique des sensations organisées, Paris, Macula, 1992, p. 56. 


\subsection{A sintaxe extensiva}

Não é outro o funcionamento da sintaxe extensiva. O "pensamento mítico", nos termos de Cassirer, opera lançando mão da "divisão" e da "conexão", da "sunagôgê"e da "diairesis" (Cassirer, 1986, p. 53); o "pensamento selvagem", segundo Lévi-Strauss, funciona por meio de "totalizações" e "destotalizações" (Lévi-Strauss, 1962, p. 193). No rastro desses dois encaminhamentos antropológicos exemplares, Tensão e significação propõe três hipóteses diretoras: (i) se a medida - a medida do afeto, por um pleonasmo necessário diz respeito à intensidade, a extensidade concerne ao próprio número do mundo e à sua distribuição em classes, que os mitos tratam de motivar; (ii) qualquer que seja o gênero adotado, o discurso opera por triagem(ns) e mistura(s); tais termos trazem a vantagem de valer tanto para os discursos verbais, quanto para os não-verbais, como demonstrou Greimas em seu estudo sobre a receita da sopa ao pesto (Greimas, 1996, p. 7-21). As taxionomias e classificações caras à antropologia se apresentam como triagens de misturas e misturas de triagens. A recorrente imbricação desses dois tipos de operações, aliás, surpreende Cassirer:

O fato de que essa mistura das 'espécies' e de que essa confusão entre seus limites naturais e espirituais sejam possiveis na consciência mitica, quando nos outros domínios esta se caracteriza pela precisão com que apreende as diferenças sensiveis que distinguem concretamente as figuras perceptiveis, tal fato - qualquer que seja a explicação específica que se dê da significação e gênese do totemismo - deve estar fundamentado num caráter geral da 'lógica' mítica, ou seja, na forma e direção de seu processo de formação dos conceitos $e$ das classes em geral. (Cassirer, 1986, p. 212).

Do mesmo modo como, para a gramática intensiva, o aumento e a diminuição convertem-se em objetos recíprocos, assim também, para a gramática extensiva, a triagem e a mistura, disjuntas no sistema, 
tornam-se objetos mútuos no processo: o sujeito semiótico não pode evitar de triar misturas, visando a um valor de absoluto, e de misturar triagens, visando a um valor de universo.

$\mathrm{Se}$, indagada a respeito, a semiótica se visse obrigada a confessar uma ontologia, esta seria, em última instância, negativa: não há antecedente intangível, há somente lembranças críveis. As grandezas circulam, vão e vêm, retornando por vezes; em outras palavras, por uma operação de triagem, elas são extraídas de uma dada classe, em parte razoável, em parte insensata, para então serem introduzidas numa outra classe mediante uma operação de mistura, ora bem-sucedida, ora incongruente - tanto é verdade, aparentemente, que para o discurso a questão não é conhecer a essência imutável das coisas, e sim estabelecer, para uma determinada grandeza, projetada pelas circunstâncias no centro do campo de presença, a lista daquelas que são, em tal ou qual momento, compatíveis com ela, e a lista daquelas que não o são. $O$ discurso não é dirigido pela busca dos predicados universais, mas pelo recenseamento, por sua vez singular, dos interditos e das combinações prescritas, uns e outros eficientes, quando não oficiantes, na cultura em questão. Diga-se de passagem que a semiótica do discurso, caso venha a tornar-se consistente, será certamente levada a moderar a solução de continuidade entre a diacronia e a sincronia, uma vez que as estruturas da sincronia têm uma vocação temporal e historicizante que não deixa dúvida: "Na lingüística, as coisas se sucedem de outro modo: aí o discurso conserva os traços das operações sintáxicas anteriormente efetuadas" (Greimas \& Courtés, s/d [1983], p. 366). Em La philosophie des formes symboliques, Cassirer demonstrou que a operação canônica de triagem recaía essencialmente sobre a delimitação dos domínios respectivos do sagrado e do profano; não iremos tão longe a esse respeito, pois, em outro ensaio, já abordamos certos pormenores que temporalizam essa circulação (Zilberberg, 2004, p. 69-101). O objeto é menos uma grandeza do que o momento em que uma alternância se muda em coexistência, em que dois elementos mutuamente exclusivos aceitam defrontar-se. 


\subsection{A discursivização}

A problemática da enunciação permitiu avaliar o controle direto e indireto que o sujeito enunciador exercia sobre o enunciado; muitos foram os estudiosos a frisar que a catálise precedia a análise. O objeto, porém, não mereceu a mesma atenção, como se ele conservasse uma autonomia e uma capacidade de fugir ao controle das coerções semióticas. A discursivização das regulações próprias à gramática tensiva refere-se, antes de mais nada, ao fato maciço, ininterrupto, da melhoração e da pejoração; a essas duas operações discursivas aplicam-se as considerações de Saussure acerca da silabação: "é, por assim dizer, o único fato que ela [a fonologia] põe em jogo de começo a fim". O discurso não descreve: a todo instante, ele toma posição e sanciona, e faz-se necessária uma convenção forte, a coerção voluntariamente assumida de um gênero discursivo, para que o sujeito do discurso se contente em descrever o que acredita ver e se abstenha de declarar sua subjetividade tal como ele próprio está acostumado a apreender.

Salvo melhor juizo, dois caminhos abrem-se para o sujeito. O primeiro incide sobre a sintaxe intensiva e diz respeito à manipulação das estruturas da contrariedade. Nesse particular, são duas as possibilidades que se oferecem ao sujeito: ou substituir o espaço da subcontrariedade pelo da sobrecontrariedade e proclamar com autoridade a insuficiência, o "não o bastante" das grandezas admitidas no campo de presença; ou fazer o contrário: substituir o espaço da sobrecontrariedade pelo da subcontrariedade, proclamando então o excesso, o "demasiado". Por recursividade, e no calor do discurso, o sujeito pode chegar a declarar a insuficiência do excesso, bem como a insuficiência da insuficiência, transformando, no primeiro caso, limites em graus, e, no segundo caso, inserindo dentro do intervalo dos subcontrários $\left[\mathrm{s}_{2} \Leftrightarrow \mathrm{s}_{3}\right.$ ] um intervalo de menor envergadura. Os valores míticos discursivizados são o sublime e o mediano. Em razão da reversibilidade dos pontos de vista, o sublime, assumindo sua própria desmedida, denuncia o mediano como sendo "nulo" - coisa que ele não é -, enquanto o mediano, em nome da ponderação, desqualifica o sublime como "empolado" e "grandiloqüente" - o que 
também não é verdade. Pois não está a eloqüência, desde sempre, dividida entre o fôlego e a justeza?

O segundo caminho motivador da qualificação e da desqualificação - que fornecem ao discurso, ambas, seus indispensáveis tempos fortes - está na dependência da sintaxe extensiva. A afirmação da superioridade intrínseca das operações de triagem sobre as operações de mistura acaba por promover a reiteração da triagem, isto é, por triar a triagem obtida, com vistas à pureza, quer se trate da pureza do diamante ou da do sangue, como na Espanha do século XVI; em todas as acepções do termo, estamos em presença de valores de absoluto, concentrados e reflexivos. A afirmação inversa, ao instalar a mistura muito acima da triagem, ao misturar as misturas, admitindo a plausibilidade de uma classe das classes, resulta no elogio dos valores de universo, difusores e transitivos. Cada uma dessas direções axiológicas oculta seu mal secreto: a proclamação dos valores de absoluto tem por limite o "nada", o "coisa alguma", a irrepreensível negatividade dos pronomes indefinidos negativos: ninguém, nenhum, nenhuma, e há quem murmure "nem mesmo Deus...". Já a proclamação dos valores de universo, levando sempre mais e mais longe a difusão das valências, anula, à sua própria revelia, a distinção, o comedimento constitutivo do sentido, em suma, a tensão própria a qualquer paradigmática. Um mundo "jansenista", em que os valores de absoluto não concedessem qualquer lugar para os valores de universo, seria um mundo de excluidos; a configuração inversa, a saber, um mundo "jesuítico" em que os valores de universo não deixassem qualquer lugar para os valores de absoluto, seria um mundo de incluídos; ora, o segredo do político reside provavelmente na delicada dosagem da exclusão e da participação, que proporciona ao "cidadão" a "tranqüilidade de espírito" louvada por Montesquieu em $O$ espírito das leis. As estruturas do político - ainda que a questão persista em não se fazer atual - são eminentemente, e talvez somente, semióticas.

A operacionalização da melhoração e da pejoração prendese sobretudo à retórica tropológica, mas a retórica comporta ou comportava uma vertente argumentativa, estudada magistralmente por Aristóteles em sua Retórica. Sua reflexão define o discurso pela 
meta utilitária, quando não prática, que escolhe (Aristóteles, 1996, p. 93), ignorando, por não ser de seu interesse, o rumor do mundo. Desejamos demonstrar, em poucas palavras, que a implicação, convocada pelo silogismo e pelo entimema, deve compor-se com a concessão, que a desmente, mas que a implicação e a concessão remetem à estrutura elementar que propusemos em 3.1. Escolheremos, pela comodidade de explanação, a declinação da direção espacial:

\section{\begin{tabular}{|l|l|l|l|l|}
\hline direção & hermético & fechado & aberto & escancarado \\
\hline
\end{tabular}}

Tal análise fornece-nos, por um lado, a oposição ingênua entre os dois subcontrários, o /aberto/ e o /fechado/ - que encaramos tanto na sua condição de enfoques possíveis para o sujeito, quanto na de morfologias estáveis - e, por outro lado, duas oposições mais "raras": (i) uma oposição entre um subcontrário, o /fechado/, e um sobrecontrário, o /hermético/, os quais se opõem como, respectivamente, aquilo que se pode abrir e aquilo que não se pode abrir. Essa tensão prova, se é que ainda resta dúvida, a dependência do espaço para com a tonicidade, a energeia, pois não é verdade que a denegação do /hermético/ exige um gasto suplementar de energia? (ii) a oposição entre o /aberto/ e o /escancarado/ é simétrica e inversa à anterior: o /aberto/ se apresenta como aquilo que se pode fechar, e o /escancarado/ é aquilo que não se pode fechar. Está claro que tais grandezas se mostram para o sujeito como possíveis e não-possiveis; elas envolvem a veridicção, a intersubjetividade e a potencialização, já que se pode facilmente catalisar que elas são tidas como tais, reputadas como tais.

Uma vez aceitas essas premissas, a implicação produzirá os sintagmas motivados: fechar o aberto e abrir o fechado, pois que o aberto é fechável ou re-fechável e o fechado, abrível. Esses traços latentes tornam supérflua a argumentação. Bem outro é o caso da concessão, já que os sintagmas canônicos aferentes são respectivamente: abrir o hermético (ou seja, abrir o que não se pode abrir) e fechar o escancarado (isto é, fechar o que não se pode fechar). A concessão, definida pelas gramáticas como a 
"causalidade inoperante", exibe assim seus méritos. A discursivização da concessão opõe o não-realizável, julgado irrealizável, e a realização advinda: embora esse dispositivo seja hermético, eu o abro!, e embora esse dispositivo esteja escancarado, eu o fecho! Passamos subitamente da ordem enfadonha da regra para a ordem tonificante do acontecimento. Os três gêneros de discursos previstos por Aristóteles prestam-se claramente à performance concessiva; por exemplo, no imaginário corriqueiro o grande advogado é o das causas desesperadas, aquele que consegue substituir o discurso da implicação pelo da concessão, aquele que sabe e ousa reverter o "porquê" da acusação em "embora", capaz de alterar, em seu benefício, a imagem do acusado no espírito dos jurados. Em resumo, os subcontrários entram no discurso convocando a implicação e os sobrecontrários, mobilizando a concessão. Todas as estruturas elementares propostas podem ser tratadas nos termos da concessão. À objeção apressada, segundo a qual a presença da implicação é maciça e até, para alguns, monótona, sendo a concessão, por sua vez, rara, retrucamos que a concessão é convertida na exclamação e que estamos na ordem descontínua do acontecimento, visto que este último, ao sobrevir no campo de presença, rompe com o sistema das expectativas vigentes.

\section{Por uma semiótica do acontecimento}

Não é necessária uma longa pesquisa para se evidenciar a latência discursiva da concessão. No quinto capítulo dos Prolegômenos, Hjelmslev, tendo indicado que "a teoria, em si mesma, não depende da experiência", acrescenta: "o teórico sabe, por experiência, que certas premissas enunciadas na teoria preenchem as condições necessárias para que esta se aplique a certos dados da experiência" (Hjelmslev, 1975, p. 16). Estivemos tratando, até agora, da arbitrariedade da teoria, mas, se o acontecimento é um dos dados capitais da experiência - fato que nos parece difícil de contestar com seriedade - podemos passar a examinar a adequação da teoria.

Pela epistemologia própria à semiótica tensiva, a descrição de uma grandeza só é possível a partir de sua inserção no espaço tensivo. A questão se coloca por si mesma: quais são as dinâmicas 
intensivas, isto é, de andamento e tonicidade, e as dinâmicas extensivas, ou seja, de temporalidade e espacialidade, que o acontecimento, por assim dizer, faz vibrar? Tendo detalhado, em 3.2 , as valências plausíveis para cada subdimensão, nossa tarefa agora não é descobri-las, mas apenas reconhecê-las no discurso.

De acordo com o Micro-Robert, o acontecimento se define como "aquilo que acontece e tem importância para o homem". A primeira indicação é mais legível que a segunda, por ser da ordem do sobrevir, da subitaneidade, ou seja, do andamento mais rápido que o homem possa experimentar. A segunda indicação, "e tem importância para o homem", refere-se à tonicidade, na medida em que esta é a modalidade humana por excelência, estabelecendo o próprio estado do sujeito de estado. O sujeito, instalado na ordem racional, programada e compartilhada do conseguir, ${ }^{13}$ senhor de suas esperas sucessivas, vê-se desviado de seus caminhos habituais e projetado em sua devastação; em outras palavras, vê-se projetado naquilo que Valéry chama, nos Cahiers, de "brusco":

Todo acontecimento brusco atinge o todo.

O brusco é um modo de propagação.

A penetração do inesperado, mais rápida que a do esperado - porém a resposta do esperado mais rápida que a do inesperado. [...] (Valéry, 1973, p. 1288)

Como já pudemos sugerir, o andamento e a tonicidade agem conjuntamente sobre o sujeito, mobilizam-no, o que significa que $o$ duplo suplemento de andamento e de tonicidade, surgindo de improviso, traduz-se, no sujeito, por um déficit daquilo a que chamamos seu comedimento, bem como por seu desmantelamento modal instantâneo; a tonicidade não vem devastar uma parte do sujeito, e sim ele todo. Para essa semiose fulgurante, o acontecimento, quando merece tal denominação, arrebata para si todo o agir, não deixando ao sujeito nada além do suportar. Do ponto de vista morfológico, e no que tange

13. [N. dos T.] No original, parvenir. 
ao afeto, a escansão previsível do restabelecimento e da exacerbação - que permite ao sujeito "adivinhar as intenções", preparar-se e esperar o ponto culminante da exacerbação - acaba não ocorrendo, pois, precisamente, o restabelecimento está virtualizado, e o sujeito se sente, nos termos que adaptamos de Valéry, "penetrado pelo inesperado", o que significaria que a minimização tampouco está sendo precedida (e por isso mesmo moderada) pela atenuação. Em ambos os casos se passa - sem transição, ou seja, sem modulação, sem cuidado-de $\left[\mathrm{s}_{1}\right]$ para $\left[\mathrm{s}_{4}\right]$, de tal sorte que diremos, do acontecimento, que ele é a um só tempo a medida e a derrota do sujeito. Se a semiótica soube reconhecer, com justiça, sua dívida para com Propp, ela desconheceu a lição de Aristóteles na Poética, a saber, que o acontecimento, no plano do conteúdo, e a teatralidade, no plano da expressão, ${ }^{14}$ constituem, a par da narrativa e do "esquema narrativo canônico", um dos caminhos possíveis do sentido.

Se nos voltarmos agora para a extensidade, as coisas também não serão simples. No que se refere à temporalidade, esta se acha como que fulminada, aniquilada; para usarmos a fórmula inigualável, o tempo "perdeu as estribeiras". Segundo Valéry, na mesma passagem, esse tempo que se perde é um tempo cumulativo, porém negativo, o qual dá origem a um estereótipo que se vivencia com freqüência: a urgência de recuperar o tempo perdido. A recomposição da temporalidade está condicionada à desaceleração e à atonização, ou seja, ao retorno àquele comedimento que o acontecimento suspendeu; o sujeito almeja reaver pouco a pouco o controle e o domínio da duração, sentir-se novamente capaz de comandar o tempo a seu bel-prazer; em outras palavras, conforme indicamos em 3.2, almeja alongar o breve ou abreviar o longo. Quanto à espacialidade, também ela é maltratada pelo acontecimento. A escansão do aberto e do fechado exigida por toda circulação é virtualizada, uma vez que, ausentando-se o aberto do campo de presença, só o fechado acaba se mantendo ali. De um sujeito estupefato, podemos dizer que ele ficou petrificado, sem poder sair

14. [N. dos T.] Cf. nota 14.

Significação $25 \cdot 199$ 
do lugar, lugar este que funcionaria, por um átimo, como um "buraco negro" que tivesse engolido seu ambiente.

\section{Para concluir}

Mesmo correndo o risco de abusar da inversão dos genitivos, diremos que o discurso da teoria deve espelhar a imagem da teoria do discurso. Isso traz duas decorrências: (i) sob o ponto de vista da extensidade, se a teoria é concebida - com razão, pois que é a demanda do momento - como "hipotético-dedutiva", um exame mais detido irá apresentá-la como uma montagem, uma receita que recicla e depois amalgama certos ingredientes "tomados aqui e ali", dos quais ela tenta tirar o melhor partido, e não faz mais que sua obrigação. Nesse sentido, a semiótica "abasteceu-se" em primeiro lugar na lingüística e na antropologia estrutural, em seguida, na fenomenologia, por vezes na psicanálise, na "teoria das catástrofes" com Petitot, mas ignorou a retórica, como arte do discurso e como tesouro das figuras. Ora, está claro que a retórica tropológica tem afinidade com as valências e operações que identificamos: assim, por exemplo, que faz uma metáfora, senão efetuar uma mistura entre duas grandezas, ora a partir de suas morfologias relevantes, ora a partir de suas características tensivas? (ii) sob o ponto de vista da intensidade, as coisas são ainda mais nítidas: não se pode dizer que haja, num primeiro momento, coisas, e, depois, qualidades; pelo contrário, há sobrevires, emergências súbitas, acentuações à cata de plausíveis significantes receptores.

Na segunda metade do século XIX, os poetas, Mallarmé à frente, sonharam "resgatar da Música o seu bem". Certos pintores também sonharam, muitas vezes no rastro de Baudelaire, musicalizar a pintura. ${ }^{15} \mathrm{Na}$ maioria das vezes, contudo, sem chegar a explicitar seriamente os termos da problemática, limitaram-se a analogias vagas

15. Por exemplo, Van Gogh: "Esse maldito mistral incomoda muito para fazer pinceladas que se sustentem e entrelacem com sentimento, como uma música tocada com emoção", citado por Nicolas Grimaldi, Le soufre et le lilas. Essai sur l'esthétique de Van Gogh, La Versanne (France), Encre marine, 1995, p. 108.

Significação $25 \cdot 200$ 
e sem real consistência. A nosso ver, a questão pertinente se coloca nos seguintes termos: seria possível transpor as "esquizias fundadoras", sem prejuízo grave, de uma semiótica a outra? Daremos aqui um único exemplo. Ninguém há de negar que a música comporta duas faces distintas, a melodia e a harmonia, ainda que, para o comum dos mortais, apenas a melodia seja memorizável e reproduzível, se não for longa demais. A analogia entre a melodia e aquilo que se denomina com justeza "fio da meada" pode evocar o que Saussure, no Curso de lingüística geral, chama de "ordem de sucessão". Todavia, excetuando-se a eufonia no plano da expressão, algumas regras elementares de concordância e a observância de certas normas socioletais aceitas pelo artista, não se vê bem o que poderia, no discurso, cumprir o papel da harmonia como dimensão reguladora do discurso musical. A musicóloga Gisèle Brelet insistiu sobre a complementaridade entre a melodia e a harmonia: "A compreensão melódica não se acha contida por inteiro no ato sucessivo de ligação: ela supõe, além da ligação sucessiva, a ligação em um conjunto simultâneo, alheio à sucessão, que reside na harmonia e depende unicamente dela" (Brelet, 1949, p. 180). Dado que essa complementaridade e essa assimetria são exatamente as mesmas que unem o processo e o sistema, de acordo com Hjelmslev, postularemos que as quatro subdimensões por nós descritas em 3.2 constituiriam, para o discurso, o equivalente da harmonia musical, uma vez safisfeitas as seguintes condições: que se atente para a "concordância", na acepção baudelairiana do termo, entre as subdimensões pertencentes a uma mesma dimensão (entre o andamento e a tonicidade, entre a temporalidade e a espacialidade) e entre as subdimensões pertencentes a dimensões distintas (entre o andamento e a espacialidade, entre a tonicidade e a temporalidade). Mas vale a pena ir além: cada um dos sistemas aferentes a uma subdimensão apresenta uma organização baseada na "interseção" de um paradigma de pontos de vista (os foremas) e de uma escala indicativa da fase aspectual em curso. Sobre essa dupla base, certos harmônicos e certas rimas motivadas podem, à maneira de passarelas, associar um sistema a outro, valendo-se, ora da identidade do forema, ora da identidade da fase aspectual. 
Forneceremos duas breves ilustrações: (i) como primeira possibilidade, temos o retardamento na dimensão do andamento e a exterioridade na dimensão da espacialidade, ambos em concordância de posição; (ii) como segunda possibilidade, a aceleração na dimensão do andamento e a tonificação na dimensão da tonicidade, que se percebe por exemplo na arte barroca, ambos em concordância aspectual. Mas uma poética da dissonância, ou seja, uma poética do acontecimento, possui a mesma legitimidade, já que lança mão dos mesmos dados. As correspondências e dissonâncias se estabelecem não entre os termos, e sim entre os determinantes tensivos que postulamos. $^{16}$

\section{Bibliografia}

ARISTÓTELES. Rhétorique. Paris : Le Livre de Poche, 1996.

BACHELARD, Gaston. La poétique de l'espace. Paris: Presses Universitaires de France, 1981.

. La dialectique de la durée. Paris: Presses Universitaires de France, 1993.

BINSWANGER, Ludwig. Le problème de l'espace en psychopathologie. Toulouse : Presses Universitaires du Mirail, 1998.

BRELET, Gisèle. Le temps musical. Essai d'une esthétique nouvelle de la musique, t. $1:$ La forme sonore et la forme rythmique. Paris: Presses Universitaires de France, 1949.

CASSIRER, Ernst. La philosophie des formes symboliques, t. I : «Le langage ». Paris : Minuit, 1985.

La philosophie des formes symboliques, t. II : « La pensée mythique ». Paris : Minuit, 1986.

16. Certos aspectos deste estudo foram abordados em Claude Zilberberg, "De l'affect à la valeur", in Marcello Castellana, op. cit., p. 43-78; tradução "Del afecto al valor", in Fronteras de la semiótica. Homenaje a Desiderio Blanco, Lima, Fondo de Cultura Económica, 1999, p. 109-142. Ver também "Forme, fonction, affect ", in R. Galassi e M. de Michiel, Louis Hjelmslev a cent'anni dalla nascita, Pádua, Circolo Glossematico, Imprimatur, 2001, p. 79-100. 
CASSIRER. La philosophie des formes symboliques, t. III : «La phénoménologie de la connaissance ». Paris : Minuit, 1988.

CLAUDEL, Paul. La philosophie du livre. In : Euvres en prose. Paris : Gallimard - La Pléiade, 1965.

DELEUZE, Gilles. Francis Bacon, logique de la sensation. Paris : Éd. de la Différence, 1984.

. Différence et répétition. Paris: Presses Universitaires de France, 1989.

FONTANILLE, Jacques e ZILBERBERG, Claude. Tensão $e$ significação. Trad. Ivã Carlos Lopes, Luiz Tatite Waldir Beividas. São Paulo : Discurso Editorial/Humanitas, 2001.

GETHE, Johann Wolfgang von. Traité des couleurs. Paris : Triades, 2000.

GREIMAS, A. J. "A sopa ao 'pistou' ou a construção de um objeto de valor ». Trad. Edith Lopes Modesto. Significação - Revista Brasileira de Semiótica, 11/12, setembro de 1996, Centro de Estudos Semióticos/AnnaBlume, 1996.

GREIMAS, A. J.; COURTÉS, J. s/d [1983]. Dicionário de semiótica. Trad. Alceu Dias Lima et alii. São Paulo: Cultrix, 1983.

GRIMALDI, Nicolas. Le soufre et le lilas. Essai sur l'esthétique de Van Gogh. La Versanne : Encre Marine, 1995.

HJELMSLEV, Louis. Prolegômenos a uma teoria da linguagem. Trad. J. Teixeira Coelho Netto. São Paulo : Perspectiva, 1975.

JAKOBSON, Roman; LÉVI-STRAUSS, Claude. "'Les Chats' de Charles Baudelaire" [1962]. In : Roman Jakobson, Questions de poétique. Paris : Seuil, 1973.

KANT, Emmanuel. Critique de la raison pure, t. I. Paris: Flammarion, 1944.

LÉVI-STRAUSS, Claude. La pensée sauvage. Paris: Plon, 1962.

VALÉRY, Paul. Cahiers, t. 1. Paris : Gallimard - La Pléiade, 1973.

ZILBERBERG, Claude. «De l'affect à la valeur ». In : Marcello Castellana (ed.), Texte et valeur, Paris/Turim/Budapeste : L'Harmattan, 2001a.

ZILBERBERG, Claude. « Forme, fonction, affect ». In : R. Galassi e M. de Michiel (orgs.), Louis Hjelmslev a cent'anni dalla nascita, Pádua : Circolo Glossematico / Imprimatur, 2001b. 
ZILBERBERG, Claude . "As condições semióticas da mestiçagem ».

Trad. I. C. Lopes e L. Tatit. In : Cañizal, Eduardo Peñuela e Caetano, Kati Eliana (orgs.). O olhar à deriva: midia, significação e cultura. São Paulo: Annablume, 2004.

ZILBERBERG, Claude - Précis de grammaire tensive.

Tangence, n. 70, automne 2002, p. $111-143$.

Tradução:

Luiz Tatit

Ivã Carlos Lopes 